due to hydrographical and, in turn, to astronomical tide-producing conditions. At a certain rare configuration of sun and moon, he said, great underwaves rolled into the Baltic from the ocean, and brought the herring where they now no longer come. At the same time the fresh waters were reduced to a shallow surface-layer, so apt to cool down and freeze that severe winters and a frozen Baltic were a common thing. All this work of Pettersson's is extraordinarily interesting; but it is very complex and very difficult, and perhaps the time has not yet come to judge it.

Pettersson and his friends were pioneers of oceano. graphy, and it was they who brought a little company together in Stockholm, in 1899 , to plan the international "Exploration of the Sea". Nansen was there, and John Murray and Otto Krümmel; Cleve was there, once a famous chemist, now one of the chief students of the micro-fauna of the surface of the sea ; Gustav Ekman came from Gothenburg and Victor Hensen from Kiel and Friedrich Heincke from Heligoland; and Johann Hjort and Martin Knudsen and I who write these lines were among the younger men. It was an honour and an education to be there.

Otto Pettersson lived two happy lives, as farmer and as scientific man. "I am a peasant," he was wont to say; it was the only English word he ever mispronounced. When I once paid him a visit at Holma he had some sixty or seventy beautiful Frisian cows in his model dairy, and he had lately built his laboratory on a little rocky island just over the way. The cliff went sheer down, and the workroom actually overhung the deep water of the Gulmarfjord. The little place was, full of gadgets; water could be pumped from various depths, and all sorts of recording instruments ticked away. A coppor vessel floating on the surface of discontinuity rose and fell with the submarine waves, and transmitted their motion to a recording drum. In fact, the devising of apparatus was one of Pettersson's special gifts, perhaps his greatest gift of all; the water-bottle which goes by his name and Nansen's was really his. Nansen, for all I know, may have somewhat improved it, and he used it and made it known; but it was Otto Pettersson who made it first, and gave it to Nansen to take with him on the Fram. Pettersson was fertile of ideas, ingenious in experiment, enthusiastic over all he took in hand to do. Age did not wither him. He kept his sturdy frame, his active mind, his warm heart, his cheerful countenance, even to extreme old age.

D'ARCY W. Thompson.

\section{Mr. Francis Druce}

Mr. Francis Druce, who was killed recently by enemy action, was well known as a botanist and collector of botanical books. He was born on January 3, 1873. Educated at Harrow and Magdalen College, Oxford, he entered the long-established firm of Druce and Attlee. In 1910 he was forced by ill-health to retire from active participation in the business (from which he completely retired in 1923), and his great love of "Nature in all her moods" led his energies into the study first of meteorology, then of his chief interest, botany. His legal experience, good judgment and methodical habits made him an ideal treasurer of scientific societies to which he belonged. In this capacity he served the Royal Meteorological Society for two periods, 1913-1918 and 1925-1932. $\mathrm{He}$ was treasurer of the Linnean Society of London from 1931 until the autumn of 1940 , when $\mathrm{h} \Theta$ became master of the Innholders' Company, of which, following the family tradition, he had previously been clerk for some years. Of the Botanical Society of the British Isles he became treasurer a few years before his death, and also took over the secretaryship when the secretary was called up for active service.

Druce formed extensive meteorological and botanical libraries. The former he presented to the Royal Meteorological Society some seven years ago, but he continued meteorological observations until his death, and when travelling always carried with him a maximum-minimum thermometer. His botanical library, except for most of his rarer herbals, was in great part destroyed in the fire which followed his death: it has been the subject of an article in the "Private Libraries" series of the Times Literary Supplement (Dec. 31, 1938). His herbarium, which mainly consisted of British plants collected by himself during the past twenty-five years, and which included almost every British species which it is possible at the present time to see in native haunts, was completely destroyed. Since 1919 I have visited most parts of the British Isles in his company, hunting rare desiderata, these ultimately becoming reduced to the 'forlorn hopes' of almost or quite extinct species. He was intrepid on rocks, and appeared quite comfortable standing on the edge of a cliff examining the slopes below through his field-glasses, which he generally carried to observe birds, of whose song (as also of good music) he was a great lover. $\mathrm{He}$ acquired a very good knowledge of the British flora and had a good eye for plants, although he himself never tackled any of the critical genera and preferred others to write up the results of his expeditions. He remained unmarried, but took great interest in the boys' clubs of his parish church in Chelsea, of which he was a strong supporter. Generous and loyal, he will be missed by a wide circle of friends.

A. J. Wпмотт.

\section{Dr. C. G. Lamb}

WE regret to record the death of Dr. Charles George Lamb, emeritus reader in electrical engineering in the University of Cambridge, on May 4.

Born in 1867, Lamb originally wished to become a professional musician; when the early death of his father made this impracticable, he went to the University of London, where he attended courses on zoology, and for a time contemplated a medical career; but he ultimately decided to study electrical engineering at the City and Guilds College, where as a student he helped to test the first alternating current transformer that was brought to Great Britain. After graduating, Lamb went to Cambridge in 1891 to assist the late Sir Alfred Ewing in his researches on the magnetic properties of iron ; in the same year 